\title{
FAKTOR YANG MEMPENGARUHI PERTUMBUHAN EKONOMI SUMATERA UTARA
}

\author{
Elly Suharyadi \\ Badan Pusat Statistik Sumatera Utara \\ Sumatera Utara, Indonesia \\ email: elly.suharyadi@bps.go.id
}

\begin{abstract}
The results from the fixed effects model analysis show that the natural resources, gross fixed capital formation, and technology have a significant and positive effect simultaneously on economic growth in North Sumatra. While labor has a nonsignificant effect on economic growth in North Sumatra. Effect of natural resources, gross fixed capital formation, and technology on economic growth is inelastic and shows a diminishing return for the all the sources of growth.

The largest source of economic growth that affects economic growth in North Sumatra is gross fixed capital formation by 0.497 and the largest increase in economic growth due to changes in the sources of economic growth is Pematangsiantar by 5,235 percent, while the smallest is Tanjungbalai City by 2,234 percent.
\end{abstract}

Keywords: Economic Growth, Sources of Economic Growth, Natural Resources, Gross Fixed Capital Formation

\section{PENDAHULUAN}

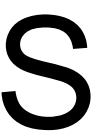

umber-sumber pertumbuhan ekonomi pada teori ekonomi berasal dari kemampuan suatu negara dalam mengembangkan potensi sumberdayanya. Makin besar kuantitas dan makin tinggi kualitas sumberdaya tersebut, maka makin besar pula potensi suatu negara untuk meningkatkan pertumbuhan ekonominya (Tanjung, 2009).

Pertumbuhan ekonomi adalah kenaikan kapasitas dalam jangka panjang dari suatu negara untuk menyediakan berbagai barang ekonomi bagi penduduknya yang ditentukan oleh kemajuan atau penyesuaian teknologi,

QE Journal | Vol.03 - No.03 September 2014 - 126 
institusional, dan ideologis terhadap tuntutan keadaan yang ada (Kuznet dalam Todaro, 2006).

Menurut Samuelson dan Nordhaus (2005), ada empat faktor sebagai sumber pertumbuhan ekonomi yaitu (1) sumberdaya alam, (2) sumberdaya manusia, (3) pembentukan modal, dan (4) teknologi.Kekayaan sumberdaya alam sangat membantu perekonomian suatu negara, walaupun belum cukup bila didukung oleh keahlian penduduk untuk mengeksplorasi sumberdaya alam.

Pembentukan modal juga merupakan faktor produksi sebagai unsur dominan untuk pertumbuhan ekonomi dimasa yang akan datang. Demikian pula, perkembangan teknologi dapat diterima secara luas sebagai sumber pertumbuhan ekonomi. Hal ini karena teknologi memungkinkan bagi produsen untuk memproduksi lebih banyak dengan tingkat input yang sama.

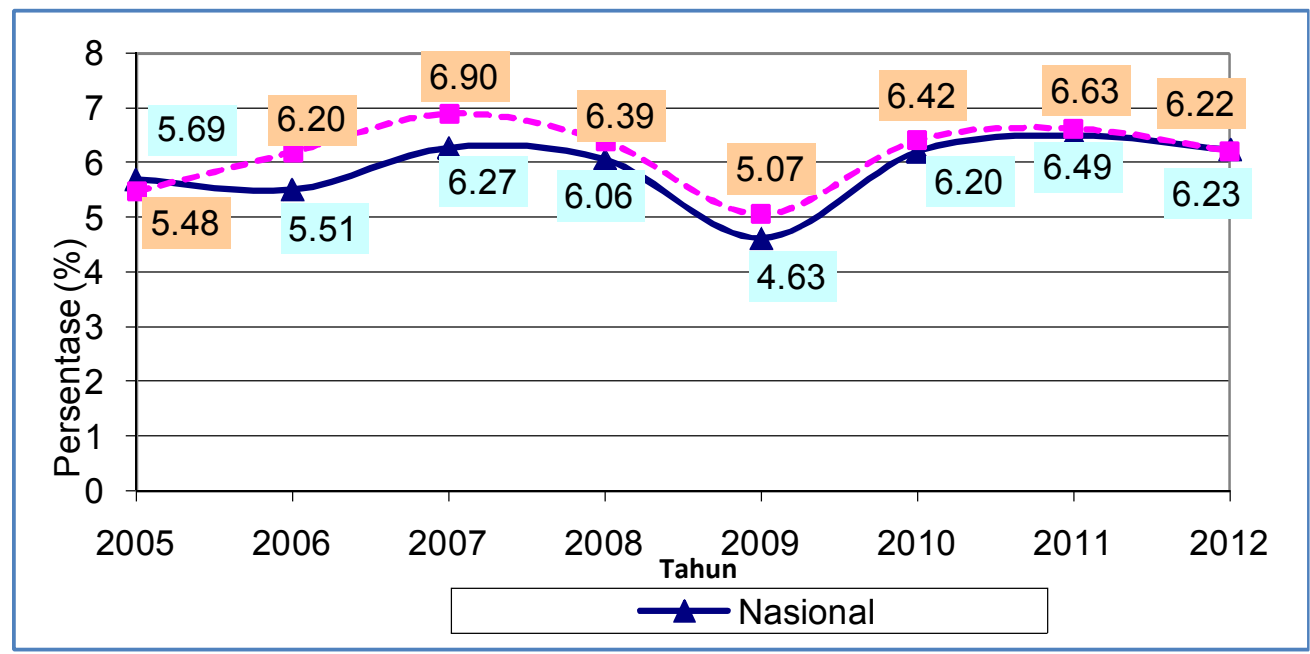

Sumber : BPS Sumatera Utara

Gambar 1. Perbandingan Laju Pertumbuhan Ekonomi Nasional dan Provinsi Sumatera Utara Atas Dasar Harga Konstan Tahun 2000 Periode 2005-2012 (\%)

Perekonomian Provinsi Sumatera Utara merupakan bagian yang tidak dapat dipisahkan dari perekonomian nasional. Selama periode tahun 20052012, laju pertumbuhan nasional maupun Provinsi Sumatera Utara dari tahun ke tahun selalu mengalami fluktuasi. 
Bila dilihat perkembangan laju pertumbuhan ekonomi antara nasional dengan Provinsi Sumatera Utara, maka laju pertumbuhan Provinsi Sumatera Utara lebih besar dibandingkan laju pertumbuhan ekonomi nasional. Secara rata-rata, pertumbuhan ekonomi Provinsi Sumatera Utara atas dasar harga konstan tahun 2000 dalam kurun waktu delapan tahun memiliki rata-rata pertumbuhan sebesar 6,16 persen tiap tahunnya. Namun dibandingkan dengan rata-rata pertumbuhan ekonomi nasional mencapai 5,88 persen setiap tahunnya, maka dapat dikatakan laju pertumbuhan ekonomi Provinsi Sumatera Utara berada di atas dari laju pertumbuhan ekonomi nasional.

Tahun 2009, terjadi perlambatan pertumbuhan ekonomi Nasional maupun Sumatera Utara bahkan terendah selama periode tahun 2005-2012. Hal ini berasal dari dampak krisis perekonomian global yang bermula dari krisis di Amerika Serikat, Eropahingga ke Asia pada semester kedua tahun 2007 yangmencapai puncaknya pada triwulan IV tahun 2008. Gejolak perekonomian global tersebut pada gilirannya mempengaruhi dinamika kestabilan makroekonomi. Tingginya resiko disektor keuangan, berdampak negatif terhadap kegiatan ekonomi disektor riil domestik. Kondisi tersebut mengakibatkan turunnya kepercayaan pelaku ekonomi disektor keuangan dan sektor riil serta menurunkan berbagai kinerja yang telah dicapai pada beberapa tahun sebelumnya.

Sejalan dengan pemulihan ekonomi global yang berangsur mulai terjadi sejak separuh pertama 2009 masih berlanjut ke tahun 2010, ditopang dengan tingginya pertumbuhan ekonomi di negara-negara emerging markets. Perekonomian Nasional dan Sumatera Utara pada tahun 2010 semakin membaik didukung oleh permintaan domestik yang solid dan kondisi eksternal yang kondusif.

Secara regional, perkembangan ekonomi Provinsi Sumatera Utara dapat dilihat dari kecenderungan perkembangan pertumbuhan ekonomi Sumatera Utara Tahun 2005-2012. Pada Gambar 2, terlihat bahwa kondisi perekonomian Sumatera Utara mulai tahun 2005 sampai tahun 2012 menunjukkan trend pertumbuhan positif. Bahkan pada tahun 2007 PDRB Sumatera Utara tumbuh sebesar 6,90 persen, yang menunjukkan terjadinya akselesari pertumbuhan yang relatif tinggi, bila dibandingkan dengan tahun 2005 dan 2006 yang hanya mampu tumbuh masing-masing sebesar 5,48 persen dan 6,20 persen.

QE Journal | Vol.03 - No.03 September 2014 - 128 
Bila dibandingkan tahun 2007, pertumbuhan ekonomi Provinsi Sumatera Utara tahun 2008-2012 memperlihatkan terjadinya fluktuasi pertumbuhan ekonomi yang hanya tumbuh masing-masing sebesar 6,39 persen, 5,07 persen, 6,42 persen, 6,63 persen dan 6,22 persen. Pertumbuhan ekonomi Provinsi Sumatera Utara tahun 2009 merupakan pertumbuhan ekonomi yang mengalami pertumbuhan yang sangat lambat selama periode tahun 2005-2012, seperti pada Gambar 2.

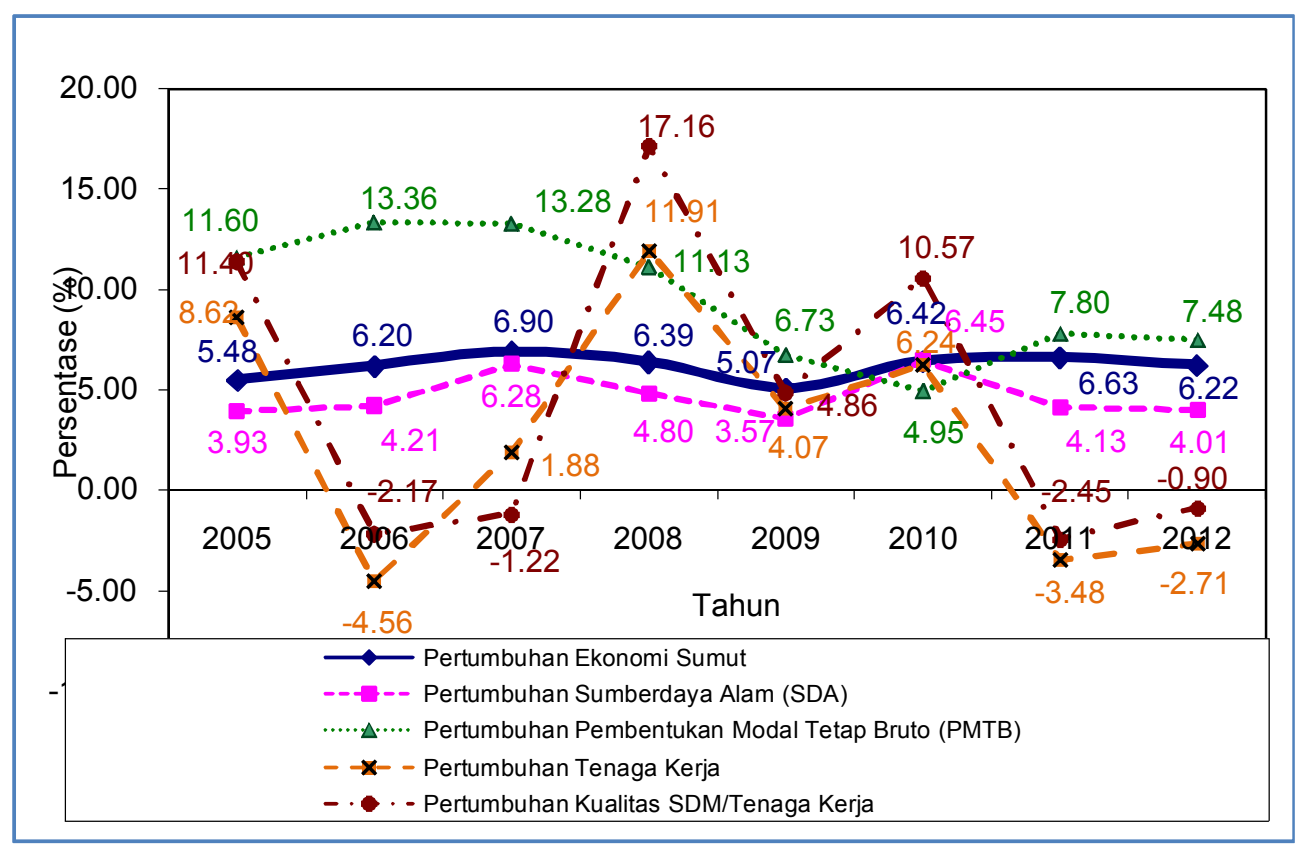

Sumber : BPS Sumatera Utara

Gambar 2. Kondisi Perekonomian Sumatera Utara 2005-2012

Pada tahun 2005-2012, sesuai dengan Peraturan Pemerintah Nomor 55 Tahun 2005 tentang Dana Perimbangan bahwa sumberdaya alam berasal dari kehutanan, pertambangan umum, perikanan, pertambangan minyak bumi, pertambangan gas bumi dan pertambangan panas bumi. Perkembangan Sumberdaya Alam (SDA) diproksikan dengan nilai tambah dari sektor kehutanan, perikanan, pertambangan dan penggalian yang dihasilkan dalam menciptakan pertumbuhan ekonomi Provinsi Sumatera Utara mengalami pertumbuhan yang positif namun berfluktuasi. Pada periode tahun yang sama pertumbuhan sumberdaya alam mengalami fluktuasi tahun 2005 sebesar 3,93 persen, tahun 2006 mengalami peningkatan menjadi 4,21 persen, tahun 2007 meningkat tumbuh menjadi

QE Journal |Vol.03 - No.03 September 2014 - 129 
6,28 persen. Tahun 2008-2009 mengalami perlambatan tumbuh yakni tahun 2008 sebesar 4,80 persen, dan tahun 2009 melambat menjadi 3,57 persen. Sementara tahun 2010 mengalami akselerasi tumbuh menjadi 6,45 persen, sedangkan tahun 2011-2012 mengalami perlambatan kembali menjadi 4,13 persen tahun 2011 dan tahun 2012 melambat menjadi 4,01 persen. Selama periode 2005-2012 pertumbuhan sumberdaya alam mengalami pertumbuhan terendah pada tahun 2009 sebesar 3,57 persen.

Pertumbuhan pembentukan modal tetap bruto menunjukkan trend pertumbuhan yang positif. Tahun 2005-2006 mengalami peningkatan pertumbuhan dari 11,61 persen tahun 2005 menjadi 13,36 persen tahun 2006. Sedangkan pada tahun 2007-2010 mengalami perlambatan pertumbuhan, dari 13,28 persen tahun 2007 menjadi 11,13 persen tahun 2008 melambat menjadi 6,73 persen tahun 2009 dan tahun 2010 melambat menjadi 4,95 persen. Sementara tahun 2011 mengalami akselerasi tumbuh menjadi 7,80 persen kemudian tahun 2012 kembali mengalami perlambatan menjadi 7,48 persen. Selama periode 2005-2012 pertumbuhan PMTB mengalami pertumbuhan terendah pada tahun 2010 sebesar 4,95 persen.

Jumlah tenaga kerja sebagai salah satu faktor produksi untuk menciptakan pertumbuhan ekonomi Provinsi Sumatera Utara mengalami trend pertumbuhan yang positif pada periode 2005-2012 kecuali tahun 2006, 2011 dan 2012. Petumbuhan jumlah tenaga kerja tahun 2005 sebesar 8,62 persen, mengalami penurunan sebesar 4,56 persen pada tahun 2006 kemudian tahun 2007 mengalami peningkatan sebesar 1,88 persen, tahun 2008 meningkat sebesar 17,16 persen, tahun 2009 mengalami perlambatan menjadi 4,07 persen dan tahun 2010 mengalami peningkatan menjadi 6,24 persen. Sementara tahun 2011-2012 mengalami penurunan, tahun 2011 pertumbuhan tenaga kerja mengalami penurunan sebesar 3,48 persen demikian juga tahun 2012 pertumbuhan tenaga kerja mengalami penurunan sebesar 2,71 persen. Selama periode 2005-2012 pertumbuhan tenaga kerja mengalami pertumbuhan terendah pada tahun 2006 sebesar negatif 4,56 persen.

Pertumbuhan kualitas Sumberdaya Manusia (SDM)/tenaga kerja yang diproksi dengan pendidikan menengah ke atas yang ditamatkan mengalami trend pertumbuhan yang positif pada periode tahun 2005-2012, kecuali tahun 2007, 2011 dan 2012 yaitu: tahun 2005 pertumbuhan QE Journal | Vol.03 - No.03 September 2014 - 130 
SDM/tenaga kerja sebesar 11,40 persen, tahun 2006 mengalami penurunan sebesar 2,17 persen, demikian juga tahun 2007 mengalami penurunan sebesar 1,22 persen, tahun 2008 meningkat menjadi 17,16 persen, tahun 2009 melambat menjadi 4,86 persen dan tahun 2010 meningkat menjadi 10,57 persen sedangkan tahun 2011 dan 2012 mengalami penurunan yakni sebesar 2,14 persen dan 0,90 persen.

Melihat fenomena ini maka ada sesuatu yang terjadi terhadap pertumbuhan ekonomi Sumatera Utara walaupun pernyataan ini harus didukung dengan penelitian lebih mendalam, seperti apa sesungguhnya yang mendasari pertumbuhan ekonomi Sumatera Utara, seberapa besar dampak dari sumber pertumbuhan ekonomi terhadap pertumbuhan ekonomi Sumatera Utara dan faktor apa yang paling dominan diantara faktor-faktor sumber bertumbuhan ekonomi tersebut, seperti: sumberdaya alam, pembentukan modal, tenaga kerja, dan teknologi.

Berdasarkan bukti empiris Norman Hick (1980)melakukan studi terhadap 83 negara-negara sedang berkembang pada periode tahun 1960-1970, bahwa hasil estimasi menunjukkan perkembangan modal manusia melalui harapan hidup dan melek huruf merupakan faktor penentu pertumbuhan output.

Barro (1991)tentang Economic Growth in a Cross Section of Countries menyimpulkan bahwa: (1) variabel SDM yang didekali dengan tingkat partisipasi sekolah (school enrollment ratio) baik SD maupun sekolah menengah mempunyai pengaruh positif $(+)$ terhadap pertumbuhan ratarata PDB per kapita; (2) tingkat pertumbuhan PDB berhubungan negative (-) dengan kontribusi pengeluaran konsumsi pemerintah terhadap PDB, tetapi berhubungan positif $(+)$ dengan kontribusi investasi public terhadap PDB; (3) tingkat pertumbuhan berhubungan negative (-) dengan kondisi ketidakstabilan bidang politik (didekati dengan jumlah revolusi dan kudeta, jumlah pembunuhan per juta penduduk), serta berhubungan negative (-) dengan adanya distorsi pasar (didekati dengan nilai purchasingpower-parity yang didasarkan atas indeks deflator PDB).

Jase De Gregoria (1992) tentang economic growth in Latin America menemukan bahwa (1) investasi (baik fisik maupun SDM) mempunyai peran penting terhadap pertumbuhan PDB riil per kapita, investasi asing berdampak positif $(+)$ tehadap pertumbuhan ekonomi dan mempunyai 
tingkat efisien yang lebih besar dibandingkan investasi domestik; (2) nilai tukar (term of trade) yang diduga berpengaruh positif (+) tidak menunjukkan hasil yang signifikan; (3) inflasi menunjukkan dampak yang negative (-) terhadap pertumbuhan ekonomi; (4) indeks keterbukaan ekonomi (didekati dengan rasio ekspor terhadap PDB, rasio ekspor bersih terhadap PDB, maupun indeks dalam WDR) yang diharapkan mempunyai dampak positif $(+)$ terhadap pertumbuhan ekonomi, tidak ada yang signifikan; (5) indikator pengembangan SDM (didekati dengan partisipasi SD dan SM, serta tingkat melek huruf), hanya indikator tingkat melek huruf saja yang signifikan.

Suahazil Nazara (1994) melakukan penelitian yang berjudul "Pertumbuhan Ekonomi Regional Indonesia: Suatu Aplikasi fungsi Produksi Agregat Indonesia, 1985-1991". Hasil yang didapat dari penelitian ini adalah kawasan timur Indonesia memerlukan infrastruktur untuk memacu pertumbuhan ekonomi sehingga penting untuk dilakukan pemerataan pembangunan dan peningkatan mutu modal manusia kekawasan tersebut.

Wibisono (2001) memperoleh bahwa variabel yang berpengaruh positif (+) terhadap pertumbuhan adalah pendidikan, angka harapan hidup, dan tingkat kematian bayi. Sedangkan tingkat fertilitas dan laju inflasi memberikan efek negative (-) terhadap tingkat pertumbuhan pendapatan.

\section{METODE PENELITIAN}

Model dasar yang akan digunakan dalam penelitian ini model pertumbuhan ekonomi Neoklasik (Solow Neo Classical Growth), dengan fungsi produksi aggregat standart yaitu:

$$
\mathbf{Y}_{\text {it }}=\mathbf{f}\left(\mathrm{A}_{\mathrm{it}}, \mathrm{K}_{1 \mathrm{it}}, \mathrm{K}_{2 \mathrm{it}}, \mathbf{L}_{\mathrm{it}}, \mathrm{E}_{\mathrm{it}}\right)
$$

dengan:

$Y_{i t}=$ Produk Domestik Regional Bruto atas dasar harga konstan 2000 kabupaten/kota i tahun $\mathrm{t}$,

$\mathrm{K}_{1 i t}=$ Sumberdaya alam kabupaten/kota i dalam tahun $\mathrm{t}$,

$\mathrm{K}_{2 i \mathrm{t}}=$ Pembentukan modal tetap bruto kabupaten/kota i dalam tahun $\mathrm{t}$,

$\mathrm{Lit}_{\mathrm{i}}=$ Kuantitas tenaga kerja kabupaten/kota i dalam tahun $\mathrm{t}$,

$E_{\text {it }}=$ Teknologi kabupaten/kota i dalam tahun $\mathrm{t}$. 


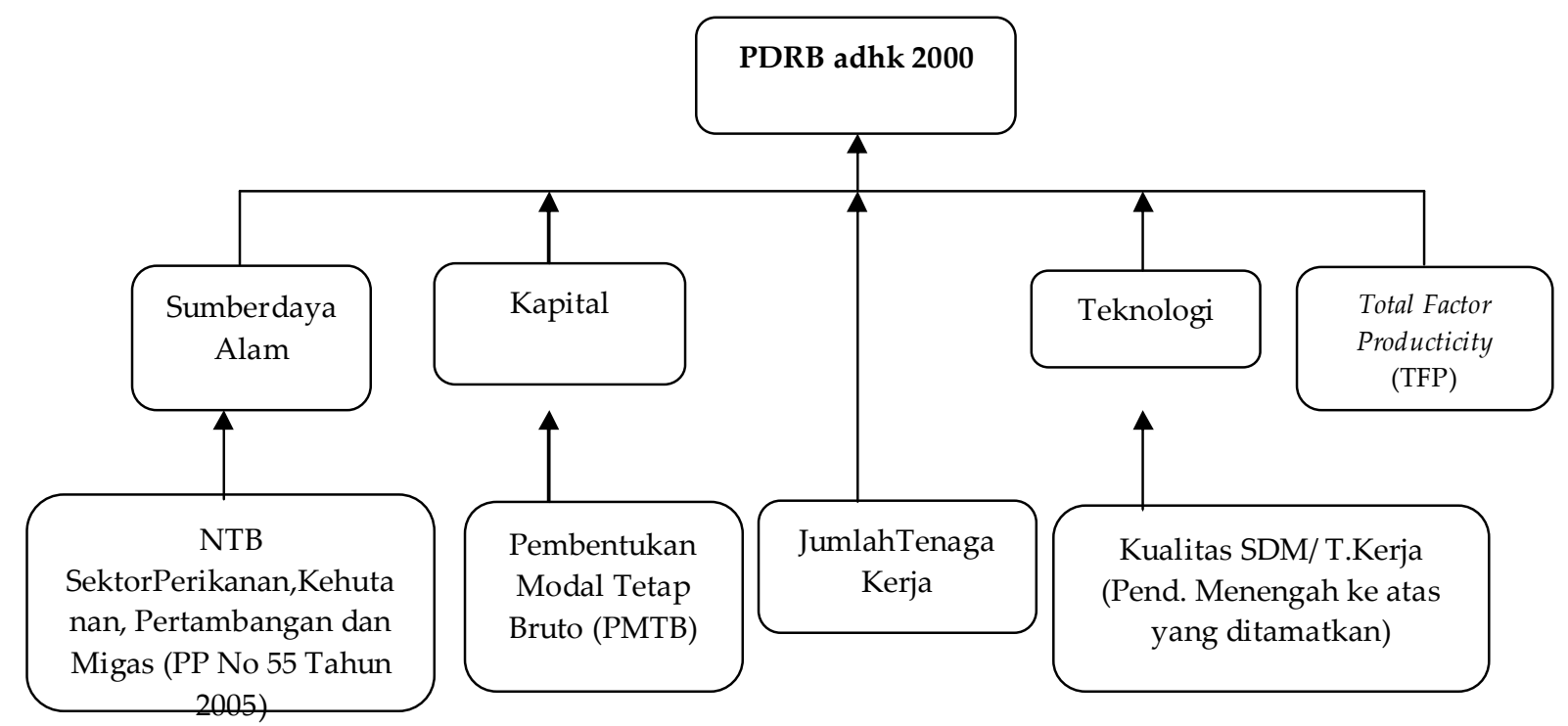

Sumber: Modifikasi dari Armstrong and Taylor, 1993 dan Bhinadi (2003) Gambar 3. Sumber Pertumbuhan Ekonomi yang Mempengaruhi PDRB Riil

Dalam studi ini model pertumbuhan di atas akan diestimasi dengan menggunakan dengan menggunakan data antar waktu (time series) dari tahun 2007-2012 dan data antar wilayah (cross-section) sehingga membentuk data panel yang terdiri dari 18 Kabupaten dan 7 Kota di Sumatera Utara.

Untuk menentukan model estimasi yang tepat, maka akan dilakukan terlebih dahulu uji spesifikasi model apa yang dipakai, apakah fixed effect, random effect atau keduanya memberikan hasil yang sama. Secara teoritis pemilihan antara model fixed effect dengan random effect dapat ditentukan. Jika dampak dari gangguan diasumsikan bersifat acak maka dipilih model random effect sebaliknya jika dampak dari gangguan diasumsikan mempunyai pengaruh yang tetap (dianggap sebagai bagian dari intersep) dipilih model fixed effect. Pemilihan model dapat juga ditentukan dengan menggunakan Hausman's Test.

Kemudian dilakukan uji ekonometrika yakni asumsi dasar dari The Classical Linear Regression Model dan Multiple LinearRegression Model adalah variabel bebas tidak berkorelasi dengan galat $(\varepsilon)$, tidak ada kolinearitas yang eksak antar variabel penjelas, galat mempunyai distribusi normal dengan rerata (expected value) sama dengan nol, $\mathrm{E}\left(\varepsilon_{\mathrm{i}}\right)=0$ dan varians setiap gatat $\left(\varepsilon_{\mathrm{i}}\right)$ konstan atau homoskedastis (homoscedasticity equalvariance) var

QE Journal |Vol.03 - No.03 September 2014 - 133 
$\left(\varepsilon_{i}\right)=\mathrm{E} \quad\left[\varepsilon_{\mathrm{i}}-\mathrm{E}\left[\varepsilon_{\mathrm{i}}\right]\right]^{2}=\sigma^{2}$. Selanjutnya dilakukan uji normalitas dengan menggunakan nilai Jacque Berra (JB), uji multikolinearitas dengan menggunakannilai variance inflanting factor (VIF), uji autokorelasi dengan menggunakan Durbin-Watson Test, uji heteroskedastisitas dengan menggunakan White Heteroscedasticity.

\section{HASIL DAN PEMBAHASAN}

Hasil regrasi menggunakan metode fixed effect dengan cross section weights diperoleh dari hasil pengujian dengan Haussman test, menghasilkan nilai Chi-square hitung sebesar 56,00 yang berarti lebih besar dari nilai Chi-square tabel dengan nilai $\alpha 5 \%$ yang sebesar 14,86 . $\mathrm{H}_{0}$ yang menyatakan bahwa model adalah random effect, maka secara statistik $\mathrm{H}_{0}$ dapat ditolak, dengan demikian diperoleh kesimpulan bahwa model yang paling baik untuk estimasi adalah model fixed effect.

Dilihat dari nilai variance inflating factor (VIF) yang diperoleh dari nilai matriks korelasi variabel-variabel bebas, tidak terdapat variabel yang memiliki nilai VIF yang lebih besar dari 5.

Tabel 1.Nilai VIF dari korelasi variable-variabel bebas

\begin{tabular}{lrrrr}
\hline \hline \multicolumn{1}{c}{$\operatorname{VIF}$} & $\log \left(\mathrm{K}_{1}\right.$ ? & $\log \left(\mathrm{K}_{2}\right.$ ? $)$ & $\log (\mathrm{L} ?)$ & $\log (\mathrm{E} ?)$ \\
\hline $\log \left(\mathrm{K}_{1}\right.$ ? $)$ & & & & \\
$\log \left(\mathrm{K}_{2}\right.$ ? & 4,3002 & & & \\
$\log (\mathrm{L}$ ? & 1,0483 & 1,0177 & & \\
$\log (\mathrm{E}$ ? & 1,1788 & 1,0254 & 4,1106 & \\
\hline
\end{tabular}

Dengan demikian diasumsikan tidak terjadi kolinieritas ganda/ multikolinearitas. Hal ini sesuai dengan teori Gujarati bahwa multikolinearitas terselesaikan dalam data panel.

Pengujian terhadap uji normalitas dengan diperoleh hasil nilai JacqueBerra(JB) yang seluruhnya lebih kecil dari nilai Chi-Square pada $\alpha 5 \%$ atau nilai probabilitanya seluruhnya lebih besar dari 0,05 artinya Ho tidak ditolak berarti tidak terjadi penyimpangan asumsi normalitas, atau pengganggu/residual terdistribusi secara normal.

NilaiDurbin Watson (DW) hitung sebesar 1,029 dengan tingkat signifikan sebesar $\alpha 5 \%, k=4$ dan $\mathrm{n}=150$ diperoleh nilai $\mathrm{dL}=1,679$ dan $\mathrm{dU}=1,788$. 
Berdasarkan hasil perbandingan antara nilai DW hitung dengan nilai DW tabel maka diasumsikan model bebas masalah autokorelasi positif.

Secara simultan variabel sumberdaya alam, pembentukan modal tetap bruto, tenaga kerja dan teknologi tersebut, menunjukkan nilai F-stat yang tinggi yaitu 8.316,93 dengan nilai probabilitas (F-Statistic $=0,000$ ). Nilai probabilitas tersebut lebih kecil dibanding $\alpha=0,05$ sehingga tidak cukup alasan untuk menerima $\mathrm{H}_{\mathrm{o}}$ berarti bahwa secara bersama-sama perubahan variabel sumberdaya alam, pembentukan modal tetap bruto, tenaga kerja dan teknologi mempengaruhi pertumbuhan ekonomi secara signifikan selama tahun 2007-2012 dengan tingkat kepercayaan 95\%.

Melalui uji $\mathrm{t}$ dua arah dengan tingkat signifikansi $\alpha=5$ persen, nilai tstatistik dan probabilitasnya masing-masing untuk sumberdaya alam hasil t.stat $=10,82$ (Prob. $=0,0000)$, pembentukan modal tetap bruto hasil t.stat. = 15,30 (Prob. $=0,0000)$, tenaga kerja hasil t.stat. $=-0,81$ (Prob. $=0,4189)$ dan teknologi hasil t.stat. $=4,52$ (Prob. $=0,0000)$ untuk dimana nilai seluruh probalitasnya lebih kecil dari $\alpha=0,05$ kecuali tenaga kerja berarti $\mathrm{H}_{0}$ ditolak dengan demikian variabel sumberdaya alam, pembentukan modal tetap bruto dan teknologi secara parsial menunjukkan pengaruh positif yang signifikan secara statistik terhadap pertumbuhan ekonomi Sumatera Utara dari tahun 2007-2012, pada tingkat kepercayaan 90 persen.

Berdasarkan hasil estimasi yang telah dilakukan didapatkan bahwa nilai $\mathrm{R}^{2}$ adjusted adalah 99,94 persen. Ini menunjukkan bahwa variabel sumberdaya alam, pembentukan modal tetap bruto, tenaga kerja dan teknologi pada model mampu menjelaskan pertumbuhan ekonomi sebesar 99,94 persen dan selebihnya hanya 0,06 dijelaskan oleh faktor faktor lain.

Dengan menggunakan model fixed effect dengan cross-section weights, maka efek individu yang dihasilkan merupakan gambaran adanya heterogenitas setiap daerah yang mencerminkan adanya faktor-faktor atau variabel lain yang dimiliki satu daerah tetapi tidak dimiliki daerah lain. Dengan kata lain daerah tersebut memiliki keunggulan atau posisi potensi relatif suatu kabupaten/kota terhadap kabupaten/kota lainnya dalam variabel lain di luar variabel bebas yang digunakan dalam model. Apabila diasumsikan variabel-variabel bebas tidak mengalami perubahan, maka masing-masing kabupaten/kota akan memiliki tingkat pertumbuhan ekonomi yang berbeda-beda karena determinan dari pertumbuhan ekonomi suatu daerah 
hanya akan tergantung dari efek individunya yaitu dari nilai konstan (intersep) ditambah dengan fixed effect (heterogenitas antar daerah).

Hai ini mencerminkan bahwa masing-masing kabupaten/kota di Sumatera Utara memiliki karekteristik yang berbeda-beda sehingga kemampuan dalam menciptakan pertumbuhan ekonomi kabupaten/kota juga berbeda. Walaupun demikian secara keseluruhan heterosgenitas antara kabupaten/kota di Sumatera Utara tidak terlalu berbeda/bervariasi.

Berikut efek dari individu masing-masing kabupaten kota yang menunjukkan posisi telatif masing-masing kabupaten/kota terhadap kabupaten/kota, sebagaimana Tabel 2.

Tabel 2. Efek Individu Kabupaten/Kota

\begin{tabular}{|c|c|c|c|c|}
\hline No. & Kabupaten/Kota & Intersep & $\begin{array}{l}\text { Koefisien } \\
\text { Fixed Effect }\end{array}$ & $\begin{array}{l}\text { Efek Individu } \\
\text { Kabupaten/ Kota }\end{array}$ \\
\hline$(1)$ & $(2)$ & (3) & $(4)$ & $(5)$ \\
\hline 1. & Nias & 3,229346 & $-0,623769$ & 2,605577 \\
\hline 2. & Mandailing Natal & 3,229346 & $-0,479470$ & 2,749876 \\
\hline 3. & Tapanuli Selatan & 3,229346 & 0,397852 & 3,627198 \\
\hline 4. & Tapanuli Tengah & 3,229346 & $-0,453024$ & 2,776322 \\
\hline 5. & Tapanuli Utara & 3,229346 & 0,355536 & 3,584882 \\
\hline 6. & Toba Samosir & 3,229346 & 0,318694 & 3,548040 \\
\hline 7. & Labuhanbatu & 3,229346 & 0,096777 & 3,326123 \\
\hline 8. & Asahan & 3,229346 & $-0,038386$ & 3,190960 \\
\hline 9. & Simalungun & 3,229346 & 0,380873 & 3,610219 \\
\hline 10. & Dairi & 3,229346 & $-0,085212$ & 3,144134 \\
\hline 11. & Karo & 3,229346 & 0,715615 & 3,944961 \\
\hline 12. & Deli Serdang & 3,229346 & 0,323457 & 3,552803 \\
\hline 13. & Langkat & 3,229346 & $-0,523058$ & 2,706288 \\
\hline 14. & Nias Selatan & 3,229346 & $-0,624116$ & 2,605230 \\
\hline 15. & Humbang Hasudutan & 3,229346 & 0,275993 & 3,505339 \\
\hline 16. & Pakpak Bharat & 3,229346 & $-0,592452$ & 2,636894 \\
\hline 17. & Samosir & 3,229346 & $-0,984773$ & 2,244573 \\
\hline 18. & Serdang Bedagai & 3,229346 & $-0,525246$ & 2,704100 \\
\hline 19. & Sibolga & 3,229346 & $-0,830777$ & 2,398569 \\
\hline 20. & Tanjungbalai & 3,229346 & $-0,995674$ & 2,233672 \\
\hline 21. & Pematangsiantar & 3,229346 & 2,005476 & 5,234822 \\
\hline 22. & Tebing Tinggi & 3,229346 & 1,460410 & 4,689756 \\
\hline 23. & Medan & 3,229346 & 0,369993 & 3,599339 \\
\hline 24. & Binjai & 3,229346 & $-0,447175$ & 2,782171 \\
\hline 25. & Padangsidimpuan & 3,229346 & 0,502456 & 3,731802 \\
\hline
\end{tabular}

QE Journal |Vol.03 - No.03 September 2014 - 136 
Dari Tabel 2 menunjukkan bahwa Kota Pematangsiantar mempunyai efek individu yang paling tinggi dibandingkan dengan daerah kabupaten/kota di Sumatera Utara. Hal ini bisa diartikan bahwa terdapat variabel lain yang dimiliki oleh Kota Pematangsiantar di luar variabel bebas di dalam model yang mampu mendorong pertumbuhan ekonomi daerahnya dibandingkan daerah-daerah lain sebesar 5,235 (ceteris paribus).

Salah satu faktor yang mempengaruhi peningkatan pertumbuhan ekonomi Kota Pematangsiantar dibandingkan dengan daerah lain di luar variabel bebas yang ada antara lain adalah kegiatan ekonomi sektor industri besar dan sedang. Hasil industri andalan Kota Pematangsiantar adalah rokok filter dan non filter serta tepung tapioka. Produksi rokok dan tepung tapioka di Kota Pematangsiantar tidak hanya dipasarkan di dalam negeri, namun juga diekspor ke luar negeri bahkan Taiwan merupakan negara tujuan penjualan tepung tapioka.

Disamping industri besar dan sedang Kota Pematangsiantar terkonsentrasi pada perdagangan dan jasa. Secara geografis Kota Pematangsiantar diapit oleh Kabupaten Simalungun yang memiliki kekayaan perkebunan karet, sawit, teh dan pertanian. Kota ini juga menghubungkan beberapa kabupaten-kabupaten lain melalui jalan darat, seperti Kabupaten Toba Samosir, Tapanuli Utara, Samosir dan Karo. Oleh karena itu, posisi yang sangat strategis sebagai Kota transit perdagangan antar kabupaten dan kota transit ke wisata Danau Toba Parapat.

Faktor yang ditimbulkan oleh sektor industri besar dan sedang, sektor perdagangan, dan sektor jasa-jasa di Kota Pematangsiantar akan menimbulkan efek tumpahan bagi proses transfer pengetahuan dan teknologi bagi tenaga kerjanya serta memicu pola pikir yang lebih maju sehingga dengan tenaga kerja yang lebih berpengetahuan dan mengerti teknologi akan meningkatkan keterampilan dan produktifitas yang pada akhirnya akan meningkatkan pertumbuhan ekonomi daerah tersebut.

Nilai koefisien mampu menunjukkan besarnya proporsi perubahan pertumbuhan ekonomi akibat perubahan sumberdaya alam, pembentukan modal tetap bruto, tenaga kerja dan teknologi sebesar 1 persen. Fungsi pengaruh sumberdaya alam, pembentukan modal tetap bruto, tenaga kerja dan teknologi terhadap pertumbuhan ekonomi berdasarkan hasil penelitian seperti terlihat pada model berikut: 


$$
\begin{aligned}
& \mathrm{y}=0,409 \mathrm{~K}_{1}+0,497 \mathrm{~K}_{2}-0,035 \mathrm{~L}+0,070 \mathrm{E}+\mathrm{e} \\
& \text { se } \quad(0,0378) \quad(0,0325) \quad(0,0428) \quad(0,0156) \\
& t \text {-stat }(10,8156) \quad(15,3009) \quad(-0,8111) \quad(4,5170) \\
& \begin{array}{llll}
\text { Prob } & \left(0,0000^{*}\right) \quad\left(0,0000^{*}\right) & \left(0,4189^{* *}\right) & \left(0,0000^{*}\right)
\end{array} \\
& R^{2} \text { adjusted }=0,9994 \\
& \text { *) signifikan pada } \alpha=5 \%, \quad{ }^{* *} \text { signifikan pada } \alpha=42 \%
\end{aligned}
$$

Dari keempat variabel tersebut mempunyai nilai koefisien terletak antara 0 sampai 1, hal ini berarti variabel sumberdaya alam, pembentukan modal tetap bruto, tenaga kerja dan teknologi ini mempunyai sifat elastisitas yang tidak elastis (inelastic). Artinya, proporsi perubahan pada keempat variabel bebas dalam jumlah yang besar akan mengubah pertumbuhan ekonomi dalam jumlah yang lebih kecil. Hal ini disebabkan faktor-faktor pertumbuhan lebih disebabkan oleh banyak faktor lain.

Besarnya koefisien secara statistik pada masing-masing variabel independen menunjukkan besarnya pengaruh masing-masing variabel dependen. Variabel pembentukan modal tetap bruto mempunyai pengaruh terbesar, kemudian sumberdaya alam dan teknologi.

Total nilai koefisien variabel bebas sebesar 0,941 lebih kecil dari satu, artinya bahwa terjadi diminising return untuk setiap input. Sesuai dengan pandangan tradisional mengenai produksi bahwa barang modal memiliki karakteristik yang dinamakan pengembalian yang semakin menurun seiring dengan meningkatkan persediaan barang modal.

Hasil estimasi menunjukkan bahwa koefisien sumberdaya alam mempunyai pengaruh kedua terbesar setelah variabel pembentukan modal tetap bruto sebesar 0,409 dengan pengaruh signifikan pada $\alpha 5 \%$ dengan probabilitas 0,000 menunjukkan bahwa hubungan antara penggunaan potensi sumberdaya alam terhadap pertumbuhan ekonomi adalah positif dan signifikan, artinya setiap kanaikan 1 persen penggunaan sumberdaya alam akan meningkatkan pertumbuhan ekonomi sebesar 0,409 persen, asumsi ceteris paribus.

Tabel 3. Hasil Uji Parsial (Uji-t) Koefisien Sumberdaya Alam

\begin{tabular}{llccc}
\hline \hline Variable & Coefficient & Std. Error & t-Statistic & Prob. \\
\hline LOG (K1?) & 0,409175 & 0,037832 & 10,81562 & 0,0000 \\
\hline \hline & QE Journal & Vol.03 & - No.03 September 2014 - 138
\end{tabular}


Peningkatan pertumbuhan ekonomi terjadi karena sumberdaya alam yang mencukupi akan lebih mudah memperoleh bahan baku untuk proses produksi dalam menghasilkan barang dan jasa dengan demikian proses produksi akan semakin lancar, lebih efisien, menekan biaya transportasi dan biaya produksi yang pada akhirnya akan meningkatkan output dan pertumbuhan ekonomi kabupaten/kota di Sumatera Utara.

Koefisien pembentukan modal tetap bruto mempunyai pengaruh terbesar terhadap pertumbuhan ekonomi di Sumatera Utara sebesar 0,497 dengan pengaruh signifikan pada $\alpha 5 \%$ dengan probabilitas 0,000 menunjukkan bahwa hubungan antara penggunaan kapital terhadap pertumbuhan ekonomi adalah positif dan signifikan, yaitu setiap kenaikan 1 persen penggunaan kapital akan meningkatkan pertumbuhan ekonomi sebesar 0,497 persen, asumsi ceteris paribus.

Tabel 4. Hasil Uji Parsial (Uji-t) Koefisien Pembentukan Modal Tetap Bruto

\begin{tabular}{lllll}
\hline \hline Variable & Coefficient & Std. Error & t-Statistic & Prob. \\
\hline LOG (K2?) & 0,497341 & 0,032504 & 15,30091 & 0,0000 \\
\hline \hline
\end{tabular}

Hubungan yang searah sejalan dengan perkembangan selama periode penelitian yang menunjukkan bahwa Sumatera Utara dari tahun ke tahun mengalami peningkatan kapital. Data menunjukkan bahwa jumlah pembentukan modal tetap bruto di Sumatera Utara tahun 2008 sebesar 20,90 triliun rupiah meningkat menjadi 27,13 triliun rupiah pada tahun 2012. Hal ini menjadi tantangan bagi pihak birokrat Provinsi Sumatera Utara, untuk mengoptimalkan iklim investasi yang kondusif. Beberapa diantaranya dengan melakukan efisiensi perijinan atau regulasi kebijakan dibidang investasi, jaminan hukum, dan ketertiban serta keamanan berusahan. Hasil temuan ini sejalan dengan hasil penelitian Barro (1991) menyatakan bahwa kontribusi investasi public terhadap PDB berpengaruh langsung terhadap pertumbuhan PDB.

Hasil estimasi tenaga kerja menunjukkan bahwa koefisien tenaga kerja dari penduduk usia 15 tahun ke atas yang bekerja tidak ada pengaruh terhadap pertumbuhan ekonomi di Sumatera Utara. Hal ini terlihat dari nilai probabilitas sebesar 0,419 artinya bahwa tidak ada pengaruh atau tidak

QE Journal | Vol.03 - No.03 September 2014 - 139 
signifikan antara ketersediaan tenaga kerja dengan pertumbuhan ekonomi (selengkapnya dapat dilihat Tabel 5).

Tabel 5. Hasil Uji Parsial (Uji-t) Koefisien Tenaga Kerja

\begin{tabular}{lllll}
\hline \hline Variable & Coefficient & Std. Error & t-Statistic & Prob. \\
\hline LOG (L?) & $-0,034679$ & 0,042756 & $-0,811086$ & 0,4189 \\
\hline
\end{tabular}

Tidak ada pengaruh antara ketersediaan tenaga kerja dengan pertumbuhan ekonomi di Sumatera Utara, hal ini disebabkan oleh terjadinya transformasi kegiatan barang dan jasa dari padat karya menjadi padat modal atau padat teknologi. Sebagai contoh pada sektor pertanian mulai dari persiapan penanaman hingga panenan telah menggunakan peralatan pertanian berbasis mesin, seperti membajak di sawah menggunakan mesin bajak kemudian pada masa panen menggunakan alat mesin pemisah gabah bahkan saat ini telah banyak usaha penggilingan padi berjalan dengan menggunakan mobil yang telah di-design sedemikian rupa, hal ini diartikan bahwa dengan menggunakan 1 orang tenaga kerja yang memakai peralatan mesin dapat menggantikan beberapa orang tenaga kerja dengan jumlah output yang sama. Sektor industri pengolahan menggunakan peralatan mesin produksi yang berteknologi sehingga mengurangi biaya produksi, hal ini berarti pada awalnya penyediaan tenaga kerja akan meningkatkan output dan pada tingkat tertentu penyediaan tenaga kerja tidak menambah output yang dihasilkan pada akhirnya tidak mempengaruhi pertumbuhan ekonomi.

Terlepas dari signifikansinya, bahwa arah dari ketersediaan tenaga kerja adalah negatif, artinya bahwa setiap kenaikan 1 persen tenaga kerja akan menurunkan pertumbuhan ekonomi sebesar 0,035 persen, asumsi ceteris paribus.

Angka negatif dari koefisien regresi tenaga kerja menunjukkan bahwa marginal produktivity of labour mengalami penurunan. Akibatnya setiap tambahan tenaga kerja di dalam setiap proses produksi, justru akan menurunkan produksi. Hal in sesuai dengan ciri produksi tahap tiga adalah menurunnya total produksi dan marginal produktivity of labour negative.

Hasil penelitian ini semakin mempertegas hasil penelitian-penelitian sebelumnya tentang pengaruh pertumbuhan tenaga kerja yang didekati

QE Journal |Vol.03 - No.03 September 2014 - 140 
oleh penduduk 15 tahun ke atas yang bekerja menurunkan pertumbuhan pendapatan perkapita (hasil penelitian Ardito, 2003).

Hasil estimasi teknologi menunjukkan bahwa koefisien teknologi yang diproksi dengan penduduk berumur 15 tahun ke atas yang bekerja berpendidikan tamatan Sekolah Lanjutan Tingkat Pertama (SLTP) ke atas mempunyai pengaruh terhadap pertumbuhan ekonomi di Sumatera Utara sebesar 0,070 dengan pengaruh signifikan pada $\alpha$ 5\% dengan probabilitas $=0,000$ menunjukkan bahwa hubungan antara teknologi terhadap pertumbuhan ekonomi adalah positif dan signifikan, yaitu setiap kenaikan 1 persen penggunaan teknologi atau kualitas tenaga kerja yang berpendidikan SLTP ke atas akan meningkatkan pertumbuhan ekonomi sebesar 0,07 persen, dengan asumsi ceteris paribus.

Tabel 6. Hasil Uji Parsial (Uji-t) Koefisien Teknologi

\begin{tabular}{lllll}
\hline \hline Variable & Coefficient & Std. Error & t-Statistic & Prob. \\
\hline LOG (E?) & 0,070313 & 0,015566 & 4,517010 & 0,0000 \\
\hline \hline
\end{tabular}

Hubungan yang searah antara teknologi dengan pertumbuhan ekonomi tersebut menunjukkan bahwa dengan bertambahnya jumlah kualitas tenaga kerja yang didekati dengan jumlah penduduk umur 15 tahun ke atas yang bekerja berpendidikan SLTP ke atas, tentu akan meningkatkan produktifitas tenaga kerja sehingga produksi output barang dan jasa yang dihasilkan juga meningkat, pada akhirnya akan meningkatkan pertumbuhan ekonomi secara positif signifikan.

Hasil penelitian ini semakin mempertegas hasil penelitian-penelitian sebelumnya tentang pengaruh sumberdaya manusia (SDM) yang didekati dengan tingkat partisipasi sekolah baik sekolah dasar (SD) maupun sekolah menengah mempunyai pengaruh positif terhadap pertumbuhan rata-rata PDB per kapita (hasil penelitian Baro, 1991).

\section{SIMPULAN DAN SARAN}

\section{Simpulan}

Sumberdaya alam, pembentukan modal tetap bruto, dan teknologi memiliki hubungan statistik yang signifikan terhadap pertumbuhan ekonomi di Provinsi Sumatera Utara. Sedangkan tenaga kerja tidak berpengaruh terhadap pertumbuhan ekonomi di Sumatera Utara. Dengan demikian, QE Journal | Vol.03 - No.03 September 2014 - 141 
analisis yang didapat menunjang hipotesa pada awal tesis yaitu sumberdaya alam, pembentukan modal tetap bruto, dan teknologi signifikan memberikan pengaruh positif terhadap pertumbuhan ekonomi daerah sedangkan tenaga kerja tidak berpengaruh atau tidak signifikan terdapat pertumbuhan ekonomi daerah.

Sumber pertumbuhan ekonomi yang paling besar memberikan pengaruh terhadap pertumbuhan ekonomi di Provinsi Sumatera Utara adalah pembentukan modal tetap bruto (PMTB), hal ini sesuai dengan fenomena yang ada di Sumatera Utara bahwa pengeluaran-pengeluaran untuk membeli barang-barang modal dan peralatan-peralatan produksi baik untuk penggantian maupun penambahan barang-barang modal dalam perekonomian yang akan digunakan untuk memproduksikan barang dan jasa.

Nilai elastisitas setiap dari semua variabel kurang dari satu, artinya sumber-sumber pertumbuhan ekonomi seperti sumberdaya alam, pembentukan modal tetap bruto, dan teknologi mempunyai sifat elastisitas yang tidak elastis (inelastic) terhadap pertumbuhan ekonomi sehingga perubahan sumber-sumber pertumbuhan ekonomi tersebut dalam jumlah yang besar akan mengubah pertumbuhan ekonomi dalam jumlah yang lebih kecil dan ketiga variabel sumber-sumber pertumbuhan ekonomi tersebut menunjukkan adanya diminishing return untuk setiap input.

Peningkatan pertumbuhan ekonomi tertinggi bila dilakukan penambahan sumber-sumber pertumbuhan ekonomi adalah Kota Pematangsiantar mempunyai efek individu yang paling tinggi dibandingkan dengan daerah kabupaten/kota di Sumatera Utara sebesar 5,235 persen (ceteris paribus), selanjutnya Kota Tebing Tinggi 4,690 persen dan paling kecil adalah Kota Tanjungbalai hanya 2,234 persen.

\section{Saran}

Sumber pertumbuhan ekonomi seperti sumberdaya alam, pembentukan modal tetap bruto, dan teknologi berpengaruh positif terhadap produktifitas output barang dan jasa oleh karena itu sumberdaya alam, pembentukan modal tetap bruto, dan teknologi perlu ditingkatkan. Sehingga pertumbuhan ekonomi diharapkan lebih berkualitas dan pembangunan lebih terarah sehingga menjadi multiplier effect terciptanya pembangunan yang berkelanjutan (sustainable devepolment).

QE Journal | Vol.03 - No.03 September 2014 - 142 
Pembentukan modal tetap bruto lebih dominan dalam mendukung pertumbuhan ekonomi suatu daerah, oleh karena itu pemerintah diharapkan mampu menjalankan peranannya untuk mengoptimalkan iklim investasi yang kondusif, diantaranya dengan melakukan efisiensi perijinan atau regulasi dibidang investasi, jaminan hukum, ketertiban dan keamanan.

Adanya keterbatasan waktu dan sumber data dalam penelitian ini, sehingga dalam penelitian selanjutnya jumlah variabel bebas dapat ditambah juga jumlah kabupaten/kota sesuai dengan kondisi daerah terakhir.

\section{DAFTAR PUSTAKA}

Amalia. 2010.Sumber Pertumbuhan Ekonomi Di Provinsi Jawa Tengah Tahun 2003-2008 [Tesis]. Yogyakarta: Program Pascasarjana UGM.

Amrulloh, Taufiq. 2006.Analisis Pengaruh Pembangunan Infrastruktur Terhadap Pertumbuhan Ekonomi Regional Di Indonesia (8 Propinsi di Sumatera). Jakarta: FE UI.

Amstrong, Harvey and Jim Taylor, 1993. Regional Economics and Policy, Second Edition, Harvester Wheatsheaf.

Ananta, A. 1987. Landasan Ekonometrika. Jakarta: Gramedia.

Ardito Bhinadi. 2003. Disparitas Pertumbuhan Ekonomi Jawa dan Luar Jawa. [Jurnal]. Ekonomi Pembangunan Volume 8 No.1. Hal: 39-48.

Asman Al Faiz. 2011. Analisis Pengaruh Pertumbuhan Ekonomi, Aglomerasi, Tingkat Pengangguran, dan Panjang Jalan Terhadap Ketimpangan antar Wilayah Menurut Tipologi Klassen pada 25 Kabupaten/kota di Provinsi Jawa Barat Tahun 2004-2008. [Skripsi]. Semarang: Fakultas Ekonomi UNDIP.

Azis, Iwan. J. 1994. Ilmu Ekonomi Regional dan Beberapa Aplikasinya di Indonesia, Jakarta: Lembaga Penerbit FE UI.

Basri, Faisal.2002. Perekonomian Indonesia: Tantangan dan harapan Bagi Kebangkitan Indonesia. Jakarata: Erlangga.

Baltagi, H. Badi. 2001. Econometric Analysis of Panel Data,Second Edition. England: John Wiley \& Sons. Chichester.

Barro, Robert J. \& Xavier Sala-i Martin. 1995. Economic Growth. New York. McGraw Hill Inc.

Becker, Gary S. 1993. Modal Manusia Suatu Analisis Teori dan Impiris University of Chicago Press. 
Boediono, 1992. Teori Pertumbuhan Ekonomi, Seri Sinopsis Pengantar Ilmu

Ekonomi, Edisi Pertama. Jogyakarta: BPFE.

BI. 2010. Laporan Perekonomian Indonesia 2009. Jakarta: BI. 2009. Laporan Perekonomian Indonesia 2010. Jakarta: BI.

BPS. 2010. Pendapatan Domestik Bruto Indonesia Menurut Lapangan Usaha. Jakarta: BPS. 2013.Sumatera Utara Dalam Angka 2013.Medan : BPS Sumatera Utara.

Deddy Rustiono. 2008. Analisis Pengaruh Investasi, Tenaga Kerja, dan Pengeluaran Pemerintah Terhadap Pertumbuhan Ekonomi di Provinsi Jawa Tengah, [Tesis]. Semarang: Program Pasca Sarjana

Greene, H. 2005. Econometric Analysis 4th Edition, USA: Prentice Hall.

Gujarati D.dan Zain S. 1999. Ekonometrika Dasar Cetakan keenam. Erlangga: Jakarta. . 2003.Ekonometrika Dasar. Erlangga: Jakarta.

Gustiar, Rahmat. 2010. Penggerombolan Kabupaten/Kota Di Provinsi Sumatera Utara Berdasarkan Variabel Kinerja Pembangunan Daerah, [Tesis]. Medan: Pasca Sarjana UNIMED.

Hsiao, C. 1989. Analisis of Panel Data. Cambridge: Cambridge University Press.

Human Development Report. 1996. Economic Growth and Human Development Technical Report, UNDP: New York

Insukindro, 2001. Ekonomi Uang dan Bank: Teori Pengalaman di Indonesia, EdisiKetiga, BPFE: Yogyakarta.

Kamaluddin, Rustian, 1999. PengantarEkonomi Pembangunan: EdisiKedua, Jakarta: Lembaga Penerbit FE UI.

Mankiw, N. Gregory, 2003.Pengantar Ekonomi. Jakarta: Erlangga. . 2006.Makroekonomi. Jakarta: Erlangga.

. 2007.TeoriMakroekonomi, (Fitria Liza dan Imam Nurmawan, Penerjemah). Jakarta: Erlangga. 2009. Intermediate Macroeconomics (7thed). Jakarta: Erlangga.

Manurung, J.J., Manurung, H.A. \& Saragih, F.F. 2005. Ekonometrika : Teori dan Aplikasi. Jakarta: PT. Elex Media Komputindo.

Masli, Lili, 2008. Analisis Faktor-Faktor yang mempengaruhi Pertumbuhan Ekonomi dan Ketimpangan Regional antar Kabupaten/Kota di Provinsi Jawa Barat.

http://www.scribd.com/doc/37939397/28/Laju-Pertumbuhan-PDRBMenurut-Komponen-Penggunaan.pdf. 28 November 20011.

QE Journal | Vol.03 - No.03 September 2014 - 144 
Nacrhowi, D. Nacrhowi dan Hardius Usman, 2006. Pendekatan Populer dan Praktis Ekonometrika Untuk Analisis Ekonomi dan Keuangan. Jakarta: Lembaga Penerbit FE UI.

Naibaho, Marlina. 2003. Pengelompokan Propinsi di Indonesia Berdasarkan Indikator Sosial-Ekonomi Tahun 2002. [Skripsi]. Jakarta: STIS.

Nicholson, W. 1991. Teori Ekonomi Mikro I. Jakarta: Raja Grafindo Persada.

Nofika, Hendri. 2005. Analisis Kinerja Pembangunan Regional di Provinsi Sumatera Selatan. [Tesis]. Palembang: Program Pasca Sarjana UNSRI.

Pyndick, Robert S and Daniel L, Rubinfield. 1998. Economics Models and Economic Forcast. New York: Mc Graw-Hill International.

Pressman,Steven. 2002. Limapuluh Pemikir Ekonomi Dunia, Jakarta: Rajagrafindo,PT.

Salahuddin, Taufiq. 2006.Analisis Penguruh Infrastruktur Terhadap Perekonomian Indonesia : Kontribusi Input-Outpt Infrastruktur dengan Metode Entropi dan Analisis Angka Pengganda. Jakarta: FE UI.

Samuelson, Paul A. dan Nordhaus, William D., 2001. Ilmu Mikroekonomi, Jakarta: PT. Media Edukasi. 2005. Economics, Eighteenth Ed., McGraw-Hill, 2005 (International Edition).

Setiadi, Elen. 2006. Pengaruh Pembangunan Infrastruktur Dasar Terhadap Pertumbuhan Ekonomi Regional Indonesia (8 Propinsi di Sumatera). Jakarta: FE UI.

Sibarani,Mauritz,H.M.2002. Kontribusi Infrastruktur Terhadap Pertumbuhan Ekonomi Indonesia (1983-1997). Jakarta: FE UI.

Simanjuntak, Payaman J. 1985. Pengantar Ekonomi Sumber Daya Manusia. Jakarta: LP-FEUI

Situmorang, Lontung Sabungan. 2011. Analisis Pengaruh Pembangunan Infrastruktur Terhadap Pertumbuhan Ekonomi provinsi Sumatera Utara. [Tesis]. Medan: Program Pasca Sarjana UNIMED.

Sukirno, Sadono. 1985. Ekonomi Pembangunan, Proses, Masalah dan Dasar Kebijakan. Jakarta: LP-FEUI

2000. Makroekonomi Modern: Perkembangan Pemikiran Dari Klasik Hingga Keynesian Baru. Raja Grafika Pustaka.

2006. Ekonomi Pembangunan Proses masalah dan Dasar Kebijakan. Edisi Ketiga Jakarta: Kencana.

Suryana. 2000. Ekonomi Pembangunan Problematika dan Pendekatan. Penerbit Salemba Empat Edisi Pertama.

QE Journal |Vol.03 - No.03 September 2014 - 145 
Tanjung, Ahmad Albar, 2009. Dampak Human Capital pada Pertumbuhan Ekonomi Provinsi Sumatera Utara. [Tesis]. Medan: Program Pasca Sarjana UNIMED.

The World Bank, 1994. Infrastructure For Development. World Bank Development Report 1994. New York: Oxford University.

Todaro, Michel P \& Smith, C Stepen. 2000. Pembangunan Ekonomi Di Dunia Ketiga, Terjemahan, Edisi Ketujuh, Jakarta: Penerbit Erlangga. 2002. Pembangunan Ekonomi di Dunia Ketiga. Edisi Ketujuh, Jakarta: Erlangga 2006. Ekonomi Pembangunan. Edisi Kesembilan Jakarta: Erlangga.

Wicaksono, C Prasetio, 2010. Analisis Disparitas Pendapatan Antar Kabupaten/Kota dan Pertumbuhan Ekonomi di Propinsi Jawa Tengah. [Skripsi]. Semarang: Fakultas Ekonomi UNDIP.

Widarjono, Agus, 2007. Ekonometrika Teori dan Aplikasi untuk Ekonomi dan Bisnis, Edisi Kedua, Jakarta: Penerbit Ekonisia.

Wooldridge, J, 2002, Economic Analysis of Cross Section and Panel Data, Cambridge: MTT Press. 